\title{
Holocene changes in the position and intensity of the southern westerly wind belt
}

\author{
Frank Lamy ${ }^{1 \star}$, Rolf Kilian ${ }^{2}$, Helge W. Arz ${ }^{3}$, Jean-Pierre Francois ${ }^{4}$, Jérôme Kaiser ${ }^{5}$, Matthias Prange ${ }^{6}$ \\ and Tatjana Steinke ${ }^{1,2}$
}

\begin{abstract}
The position and intensity of the southern westerly wind belt varies seasonally as a consequence of changes in sea surface temperature. During the austral winter, the belt expands northward and the wind intensity in the core decreases. Conversely, during the summer, the belt contracts, and the intensity within the core is strengthened. Reconstructions of the westerly winds since the last glacial maximum, however, have suggested that changes at a single site reflected shifts throughout the entire southern wind belt ${ }^{1-4}$. Here we use sedimentological and pollen records to reconstruct precipitation patterns over the past $12,500 \mathrm{yr}$ from sites along the windward side of the Andes. Precipitation at the sites, located in the present core and northern margin of the westerlies, is driven almost entirely by the wind belt ${ }^{5}$, and can be used to reconstruct its intensity. Rather than varying coherently throughout the Holocene epoch, we find a distinct anti-phasing of wind strength between the core and northern margin over multi-millennial timescales. During the early Holocene, the core westerlies were strong whereas the northern margin westerlies were weak. We observe the opposite pattern in the late Holocene. As this variation resembles modern seasonal variability, we suggest that our observed changes in westerly wind strength can best be explained by variations in sea surface temperature in the eastern South Pacific Ocean.
\end{abstract}

Chile is ideally located to reconstruct past variability of the southern westerly wind belt (SWW) as the SWW almost entirely controls precipitation on the western side of the Andes in southern South America with an extreme north-south rainfall gradient from the semiarid, winter-rain climate in central Chile to yearround hyper-humid conditions in the fjord region of southern Chile $^{5}$ (Supplementary Fig. S1). Therefore, any paleoclimatic proxy record primarily controlled by rainfall changes is suitable for reconstructing past changes in the SWW in this region. In present-day austral winters, the SWW extends northward, providing rainfall to central Chile $\left(33^{\circ}-40^{\circ} \mathrm{S}\right)$, but zonal winds are reduced in its core zone in southernmost Chile $\left(50^{\circ}-55^{\circ} \mathrm{S}\right.$; Fig. 1a). During austral summer, the zonal wind pattern shows a latitudinally more confined and intensified SWW with maxima over southernmost Chile (Fig. 1b). Previous reconstructions of the SWW were primarily based on single sites and generally suggested a northward migration and intensification of the SWW during colder periods $s^{1,2,4}$. Intensity variations across the wind belt have only recently been addressed and interpreted in terms of co-varying moisture changes in southern and central Chile over the Holocene ${ }^{3}$. However, this inference is only based on two single pollen records, located at $41^{\circ} \mathrm{S}$ and $51^{\circ} \mathrm{S}$, from which the southern record (Paine; Fig. 1d) misses a straightforward relation to westerly wind strength changes similar to other records on the eastern side of the Andes (for example, Potrok Aike ${ }^{2}$; Fig. 1d; Supplementary Discussion S1).

The present SWW core is centred at $\sim 50^{\circ}-55^{\circ} \mathrm{S}$, where annual precipitation reaches very high values on the windward side $(3,000-10,000 \mathrm{~mm})$, with a summer maximum correlating to stronger westerly winds (Fig. 1a,b; ref. 6). Our multi-millennialscale Holocene SWW reconstruction is based on three marine sediment cores, one lacustrine record, and a peat-bog pollen record from different sites along the fjord system near the westernmost Strait of Magellan $\left(\sim 53^{\circ} \mathrm{S}\right)$ and from the Skyring fjord east of the Andean climate divide (Fig. 1d). The records have well constrained age-models (Supplementary Table S1) based on radiocarbon dating and the occurrence of regional ash layers during the Holocene ${ }^{7}$. Depending on the individual setting, our rainfall and wind strength reconstructions are based on different proxies (Supplementary Discussion S2).

From the Skyring fjord system east of the Andean crest, we provide a record of wind-induced long-distance transport $(>100 \mathrm{~km})$ of illite and chlorite-rich clays with a clear Andean signature (Fig. 2b; Supplementary Fig. S2). We interpret this record directly in terms of westerly wind strength largely independent of precipitation changes. At site Palm2, we use strong fluctuations of biogenic carbonate accumulation-rates (AR) as a proxy for salinity changes in superficial fjord waters (Fig. 2c). Today, lower salinities occur during times of elevated precipitation and stronger winds that keep the low-salinity fjord waters inside and diminish the open marine influence on the fjord system, reducing biogenic carbonate production. At fjord Site TM1, we use AR of siliciclastic components (Fig. 2d) and terrestrial organic carbon (Fig. 2e) as recorders for fluvial supply. These records are complemented by terrestrial organic carbon AR data (Fig. 2f) from core TML1 retrieved from nearby located Lake Tamar. Core TML1 contains several terrestrial mass flow layers deposited during extreme early Holocene rainfall events (Fig. 2f; Supplementary Fig. S3). Our pollen data from Lake Tamar support the idea of an underlying climatic driving mechanism in the genesis of the mass flow layers, and offer additional precipitation and wind strength-related proxy records (Fig. 2g; Supplementary Figs S4 and S5). From close to the rainfall maximum at the Gran Campo Nevado mountain range, we further include a peat-bog pollen record (GC2) of the

\footnotetext{
${ }^{1}$ Alfred Wegener Institut für Polar- und Meeresforschung, Am Alten Hafen 26, 27568 Bremerhaven, Germany, ${ }^{2}$ Lehrstuhl für Geologie, Fachbereich Geowissenschaften (FB VI), Universität Trier, 54286 Trier, Germany, ${ }^{3}$ Leibniz Institute for Baltic Sea Research Warnemünde, Seestraße 15, 18119 Rostock-Warnemünde, Germany, ${ }^{4}$ Seminar für Geographie und ihre Didaktik, Universität Köln, Gronewaldstr 2, 50931 Köln, Germany, ${ }^{5}$ UMR 7159 LOCEAN, Université Pierre et Marie Curie, 4 place Jussieu, 75252 Paris, France, ${ }^{6}$ MARUM Center for Marine Environmental Sciences and Department of Geosciences, University of Bremen, 28334 Bremen, Germany. *e-mail: Frank.Lamy@awi.de.
} 
a

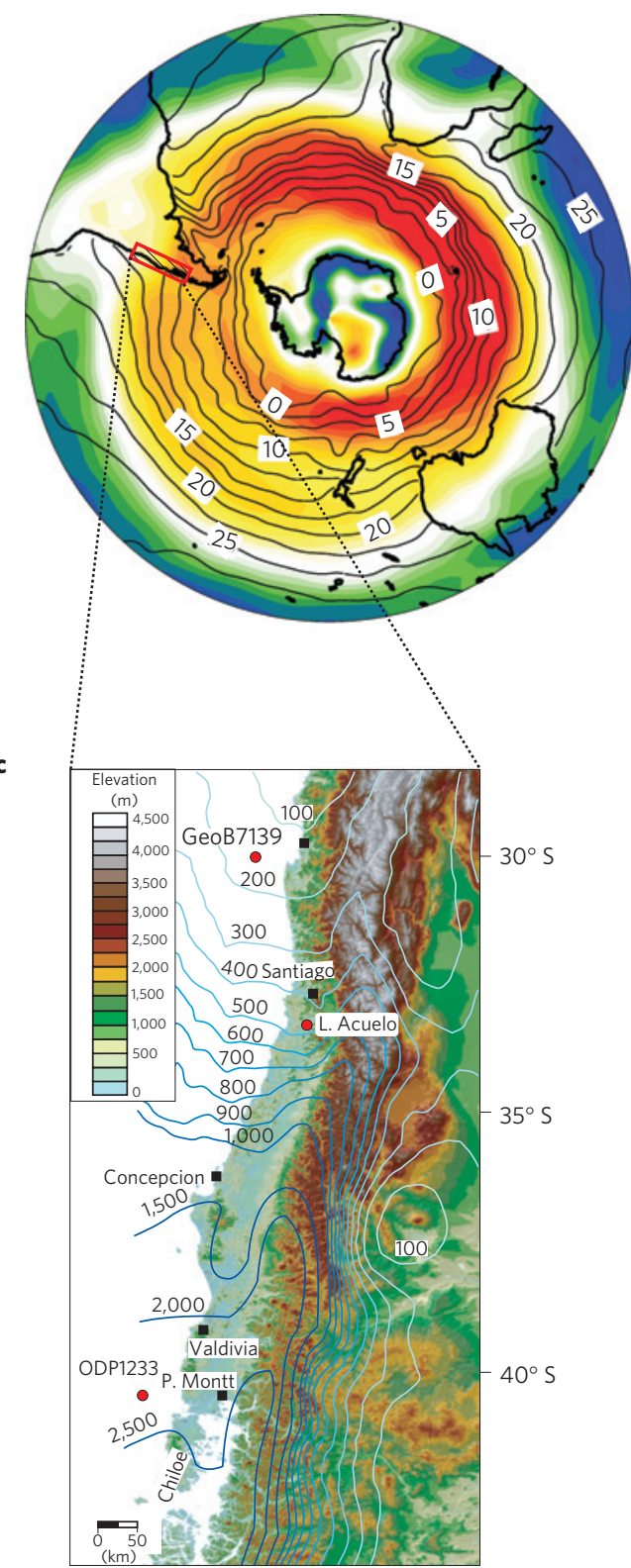

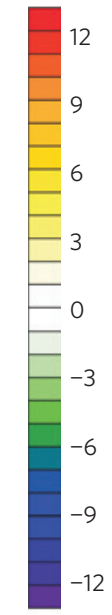

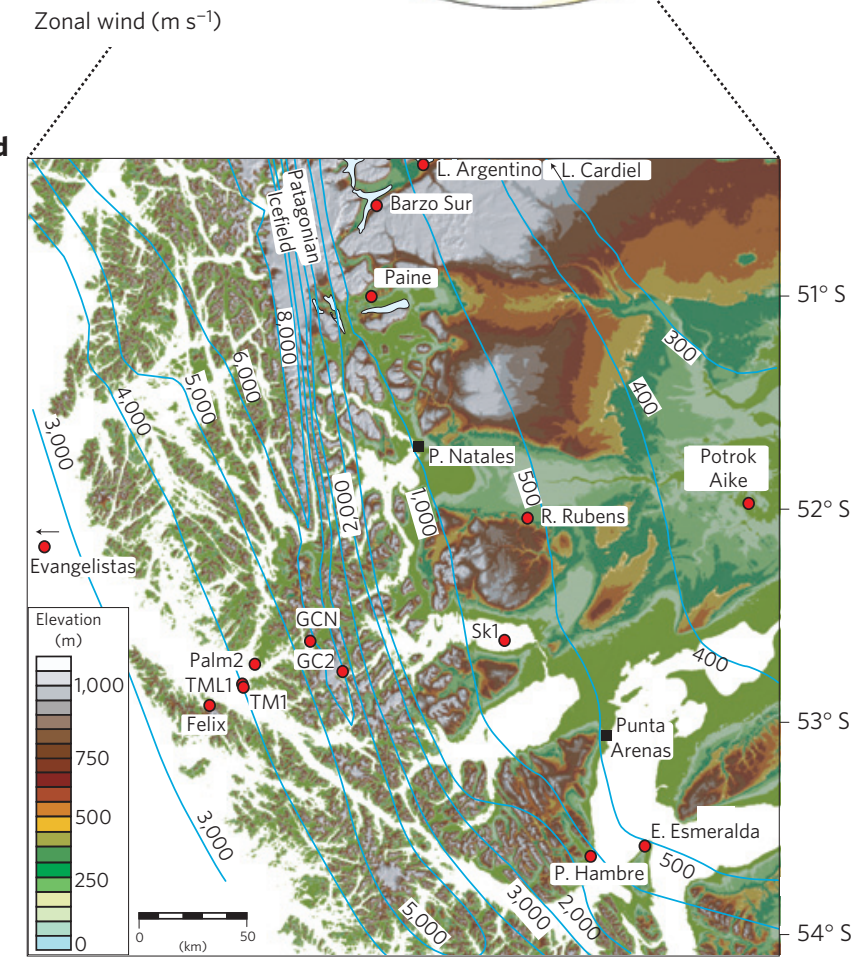

Figure 1 | Modern climatology and setting. $\mathbf{a}$, $\mathrm{SH}$ zonal wind $\left(\mathrm{m} \mathrm{s}^{-1}\right)$ climatology at $850 \mathrm{hPa}$ for austral winter and $\mathbf{b}$, austral summer based on NCEP/NCAR reanalysis data ${ }^{27}$. Overlaid isotherms are climatological sea surface temperatures $\left({ }^{\circ} \mathrm{C}\right)$ for the corresponding seasons based on the NODC World Ocean Atlas (1998). c, Topographic map of central Chile with annual precipitation in millimetres (ref. 28) (primarily winter-rain) and the location of paleoclimate records discussed in the text. $\mathbf{d}$, Topographic map of southernmost Chile with annual precipitation in millimetres (refs 6,28$)$ and the location of paleoclimate records discussed in the text.

percentage of hygrophytic taxa (Fig. 2f) as a sensitive proxy for Holocene precipitation changes in extremely humid environments (Supplementary Figs S6 and S7).

Despite individual differences between the records due to potential local overprints and the very diverse nature of the different proxies (Supplementary Discussion S2), our SWW core zone records show a clear multi-millennial pattern (Fig. 2). Most records reveal a trend towards wetter/windier conditions starting at $\sim 12.5$ thousand year before present ( $\mathrm{kyr} \mathrm{BP}$ ), a maximum between $\sim 12$ and $\sim 8.5 \mathrm{kyr}$ вP, intermediate conditions thereafter until $\sim 5.5 \mathrm{kyr}$ $\mathrm{BP}$, and finally reduced precipitation and less intense westerlies during the late Holocene. Previous reconstructions within the SWW core zone were primarily based on pollen records from southeast Patagonia (for example, Potrok Aike ${ }^{2}$, Paine ${ }^{3}$; Fig. 1d) and are partly inconsistent with our results. However, all previous reconstructions in this latitudinal band were based on records from the lee side of the Andes where other than westerly related rainfall sources become more important ${ }^{8}$. Moreover, plant communities at the dry lee side respond rather indirectly to SWW changes, as wind-induced dry stress is a major ecological factor in this region ${ }^{9}$. Such an interpretation may reconcile inconsistencies with our records (Supplementary Discussion S1).

At the northern margin of the SWW in central Chile (Fig. 1c), reconstructed rainfall changes are generally antiphased to those in the core zone in southern Chile. Figure 2a shows a rainfall reconstruction based on the hydrological balance of Lake Aculeo, located in the winter-rain domain at $\sim 34^{\circ} \mathrm{S}$ (ref. 10). Although the record only reaches back to $\sim 10 \mathrm{kyr} \mathrm{BP}$, substantially lower rainfall 


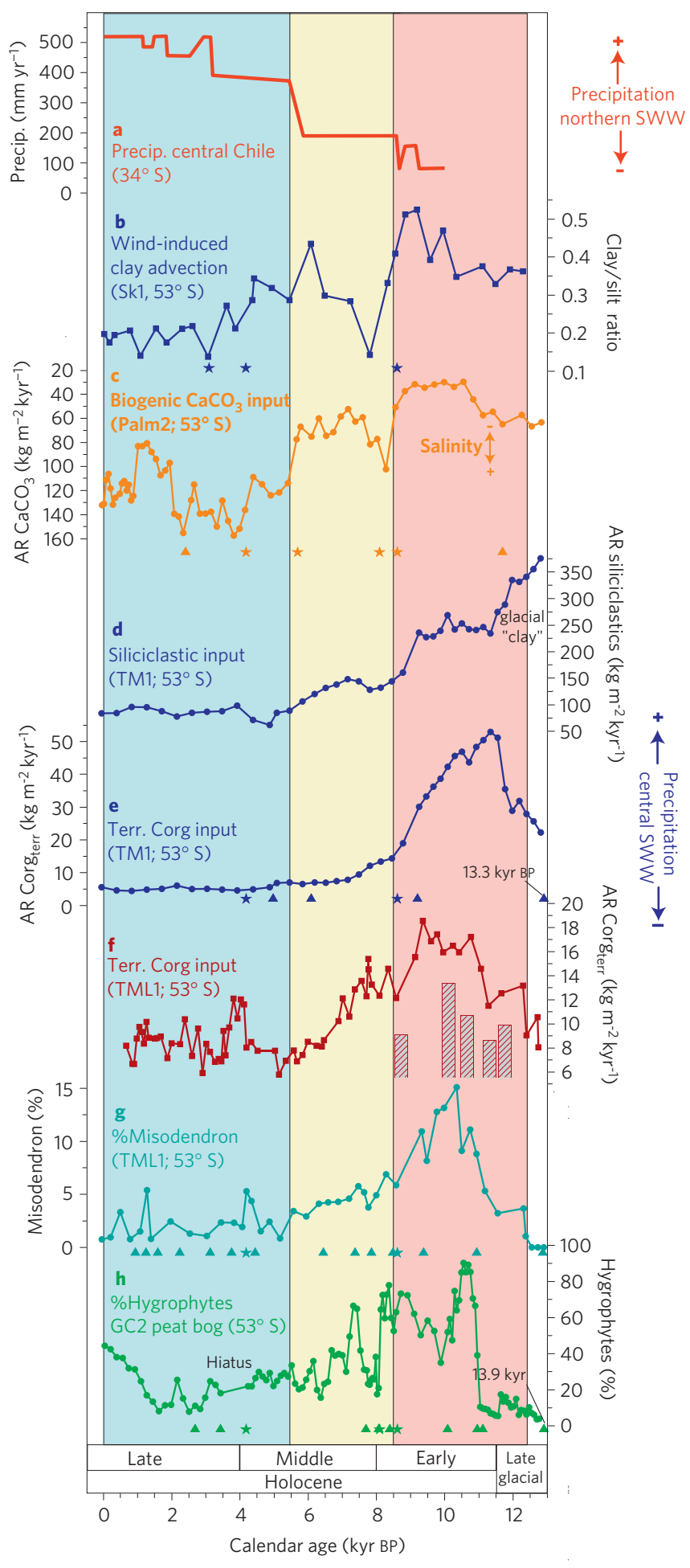

Figure 2 | Proxy records for precipitation and wind strength in the core SWW $\left(\sim 53^{\circ} \mathrm{S}\right)$ and at the northern SWW margin $\left(\sim 34^{\circ} \mathrm{S}\right)$. a, Rainfall reconstruction from Lake Aculeo ${ }^{10} . \mathbf{b}$, Clay/silt ratios from core Sk1. c, Biogenic carbonate AR from core Palm2 (reversed $y$-scale). d, AR of siliciclastic material at site TM1 and $\mathbf{e}$, terrestrial organic carbon ( Corg $_{\text {terr }}$ )AR from core TM1. f, Corg terr AR from core TML1. Vertical bars indicate the occurrence and thickness $(13-34 \mathrm{~cm})$ of terrestrial mass flow layers. $\mathbf{g}$, Relative pollen percentages of Misodendron (core TML1). h, Pollen percentage of hygrophytic taxa (core GC2). Triangles indicate radiocarbon dates and stars ash-layers. Coloured bars distinguish the early (red), middle (yellow), and late Holocene (blue) multi-millennial phases in the evolution of the SWW. during the early Holocene, and thus reduced westerly influence, has been reconstructed in the whole central Chilean region south to the Chilean Lake district and Chiloe ${ }^{11}$ (Supplementary Discussion S1). Especially after $\sim 5.5 \mathrm{kyr}$ вр, rainfall substantially increases at Lake Aculeo (Fig. 2a) and also most other central Chilean records reveal wetter conditions coinciding with drier and less windy conditions in the southern fjords (Fig. 2).

This emerging pattern of antiphased intensity changes of the SWW in the centre and northern margin strongly resembles the observed changes over the present seasonal cycle (Fig. 1a,b). This analogy suggests that the early Holocene was characterized by mean more summer-like conditions of the westerlies versus a more winter-like pattern in the late Holocene. Surface westerlies result from the meridional transport of westerly momentum by transient eddies which acts against losses by surface friction ${ }^{12}$. The eddies, in turn, are driven by the potential energy available in the meridional temperature gradients ${ }^{13}$. In the ocean-dominated southern hemisphere (SH), eddy activity, momentum flux convergence and hence the strength and position of the SWW are therefore primarily controlled by sea surface temperatures (SST) (Fig. 1a,b).

The early Holocene SWW core maximum coincides with a widespread warming at SH mid-latitudes, as evidenced by SST records from the Atlantic sector $\left(53^{\circ} \mathrm{S}\right.$; ref. 14; Fig. $\left.3 \mathrm{f}\right)$ as well as offshore central (ODP Site $1233 ; 41^{\circ} \mathrm{S}$ ) and northern Chile (Site GeoB7139; $30^{\circ}$ S; refs 4,15; Fig. 3d,e). The pronounced mid-latitude ocean surface warming supports a summer-like early Holocene scenario, as modern SST observations reveal the strongest summer warming between $20^{\circ} \mathrm{S}$ and $50^{\circ} \mathrm{S}$ (Supplementary Fig. S8). At the same time, SSTs in the eastern tropical Pacific were relatively cold $^{16}$ (Fig. 3c), reducing the mid- to low latitude SST gradient in the South Pacific. This pattern would be consistent with reduced early Holocene westerlies at their northern margin, as it appears at present during summer when the SST gradient between mid latitudes and the equator is at a minimum (Supplementary Fig. S8).

The SH early Holocene thermal maximum and coinciding SWW enhancement in the centre of the wind belt is difficult to explain by orbital forcing, as $\mathrm{SH}$ summer insolation was at a minimum (Fig. $3 \mathrm{~h}$ ). Although some climate models produce warmer-thanpresent annual-mean SSTs in the early Holocene South Pacific in response to orbital forcing ${ }^{17}$, the simulated temperature anomalies are much smaller than those suggested by the proxy records. Additional SH warming during the early Holocene might be attributable to changes in the global ocean circulation which involve a bipolar seesaw-like surface temperature pattern. A response of the SWW to changes in the Atlantic meridional overturning circulation (AMOC) strength has been previously proposed for Termination 1 (ref. 4). For the early Holocene, such a mechanism has been invoked for explaining warm temperatures in the Southern Ocean and Antarctica ${ }^{18}$ and is consistent with a reconstruction of the AMOC strength in the North Atlantic ${ }^{19}$ (Fig. 3b). This explanation implies that the AMOC reduction, starting with melt-water input during the northern hemisphere Younger Dryas, combines with the early Holocene final melting of the Laurentian ice-sheet to induce the temperature maximum extending from $\sim 12.5$ to $\sim 8.5 \mathrm{kyr}$ вр in the south. The warming may have been amplified by reduced sea-ice cover in the Southern Ocean, consistent with paleodata ${ }^{14}$.

The late Holocene cooling in the SH mid-latitudes (Fig. 3d,e) and more modern winter-like SWW pattern coincide with progressive warming of the eastern tropical Pacific (Fig. 3c) enhancing the mid- to low latitude SST gradient in the ocean basin (Fig. 3g,h). The tropical Pacific warming can be interpreted in terms of a southward movement of the Pacific Intertropical Convergence Zone enhancing atmospheric pressure gradients at the northern margin of the SWW, consistent with the suggested strengthening there. The late Holocene time-interval probably corresponds to mean more El Niño-like conditions ${ }^{20}$. The impact 


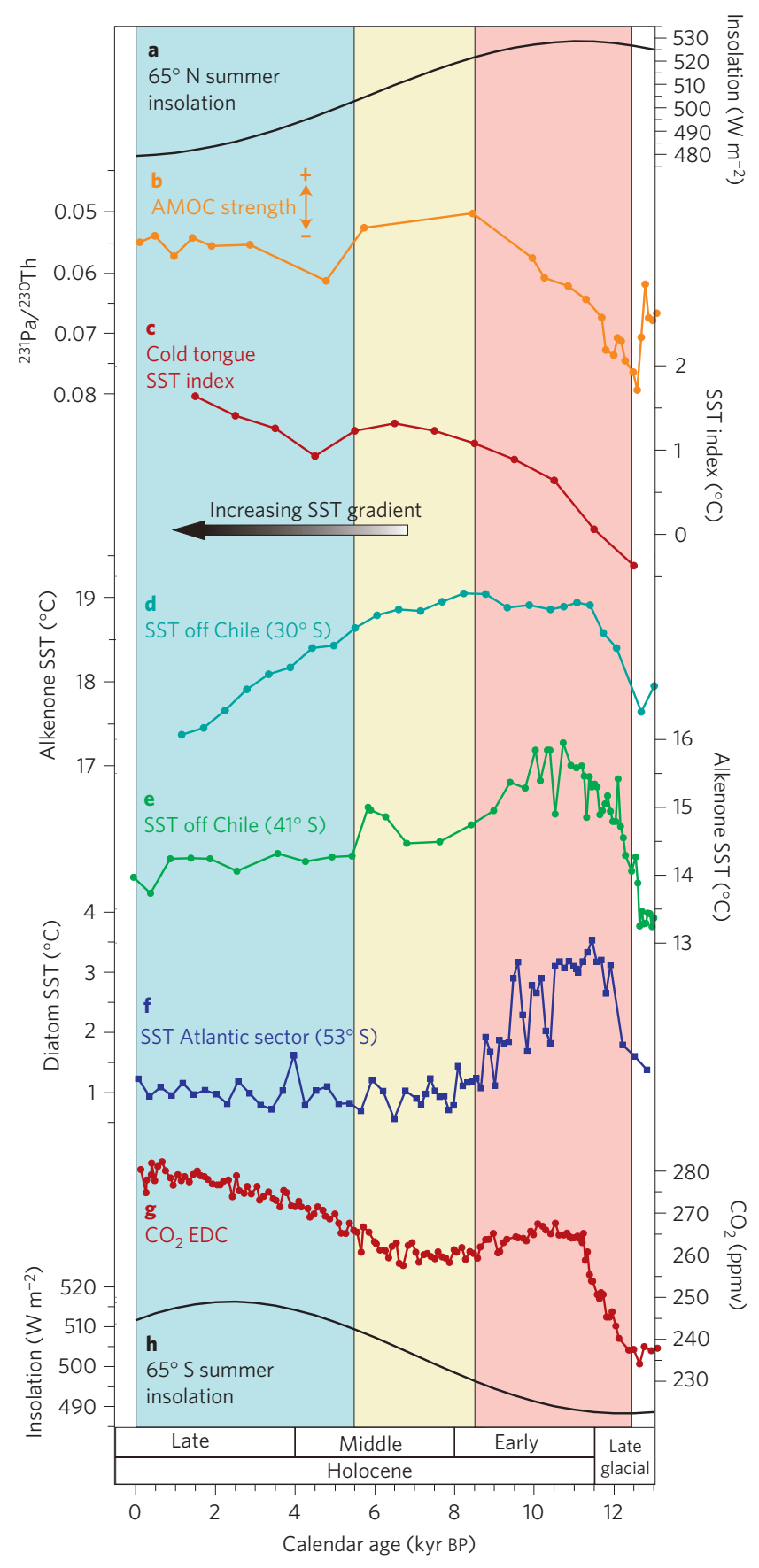

Figure 3 | Compilation of paleoclimatic records to explain Holocene SWW changes. a, Summer insolation (21 June) at $65^{\circ} \mathrm{N}$ (ref. 29). b, ${ }^{231} \mathrm{~Pa} /{ }^{230} \mathrm{Th}$ record from a subtropical North Atlantic sediment core taken as a proxy for the strength of the Atlantic meridional overturning circulation ${ }^{19}$.

c, Composite alkenone SST index from the eastern Pacific equatorial cold tongue ${ }^{16}$. d, Alkenone SST record from the Chilean margin at $\sim 30^{\circ} \mathrm{S}$ (ref. 15). e, Alkenone SST record from the Chilean margin at $\sim 41^{\circ} \mathrm{S}$ (ref. 4). f, Diatom assemblage-based summer SST record from the Atlantic sector of the Southern Ocean at $\sim 53^{\circ} \mathrm{S}$ (ref. 14). $\mathbf{g}, \mathrm{CO}_{2}$ record from the EDC ice-core ${ }^{24}$. h, Summer insolation (21 December) at $65^{\circ} \mathrm{S}$ (ref. 29).

Coloured bars as in Fig. 2.

of mean more El Niño-like conditions on the SWW is consistent with our data, as the late Holocene enhancement of rainfall at the northern margin of the SWW and concurrent reduction in the centre exactly fits the modern precipitation pattern during El Niño events ${ }^{21}$.
Our comparison of SWW records from the northern margin and the central part of the wind belt suggests antiphased intensity changes in both regions. This pattern has implications for reconstructions of the glacial westerlies, which are mainly based on proxy records from the northern margin of the SWW (refs 1,4). Although we cannot reconstruct meridional shifts of the central SWW, as our records only cover a small latitudinal band in the south, the analogy to modern seasonal changes implies that a latitudinal expansion of the SWW during cold phases ('winter-like') and contraction during warm climate conditions ('summer-like') may have been likewise important for the behaviour of the SWW on glacial/interglacial time-scales and over glacial millennial-scale fluctuations. Meridional shifts and intensity changes of the SWW have been related to changes in Southern Ocean ventilation affecting atmospheric carbon dioxide $\left(\mathrm{CO}_{2}\right)$ content ${ }^{22}$. Although such an impact of the SWW has been recently doubted, based on modelling studies $^{23}$, the similar timing of the SWW and $\mathrm{CO}_{2}$ proposed for Termination 1 (refs 4,22) appears to extend into the early Holocene. The intensification and latitudinal compression of the SWW based on our reconstruction parallels the early Holocene $\mathrm{CO}_{2}$ maximum shown in ice-cores ${ }^{24}$ (Fig. 3g), consistent with enhanced ocean ventilation. This connection breaks down in the middle and late Holocene, during which the $\mathrm{CO}_{2}$ content was probably no longer controlled primarily by Southern Ocean processes ${ }^{25}$.

Independent of any potential SWW-atmospheric $\mathrm{CO}_{2}$ relation, the early Holocene strengthening of the SWW in the centre and its reduction at the northern margin may serve as an analogue for future climate patterns under warmer-than-present conditions. If this analogy is valid, our results suggest substantial rainfall reductions in the highly populated winter-rain zone of Chile over the coming centuries, consistent with model results for future climate scenarios ${ }^{26}$.

\section{Methods}

The fjord and lake sediment cores were retrieved with a UWITEC piston corer from platforms during various cruises aboard the R/V Gran Campo II. To ensure the recovery of modern sediment surfaces, short gravity cores from the same core location have been appended to the top of piston cores (up to $18 \mathrm{~cm}$, correlation through physical properties data). The peat bog core GC2 was obtained with a Russian and a Wardenaar corer. The methods used vary among the individual records. We have therefore included information on the methods applied in the supplementary discussion of the records (Supplementary Discussion S2).

Received 22 November 2009; accepted 12 August 2010; published online 26 September 2010

\section{References}

1. Heusser, C. J. Southern Westerlies during the Last Glacial Maximum. Quat. Res. 31, 423-425 (1989).

2. Mayr, C. et al. Holocene variability of the Southern Hemisphere westerlies in Argentinean Patagonia (52 S). Quat. Sci. Rev. 26, 579-584 (2007).

3. Moreno, P. I., Francois, J. P., Moy, C. M. \& Villa-Martinez, R. Covariability of the Southern Westerlies and atmospheric $\mathrm{CO}_{2}$ during the Holocene. Geology 38, 727-730 (2010).

4. Lamy, F. et al. Modulation of the bipolar seesaw in the Southeast Pacific during Termination 1. Earth Planet. Sci. Lett. 259, 400-413 (2007).

5. Garreaud, R. D. Precipitation and circulation covariability in the extratropics. J. Clim. 20, 4789-4797 (2007)

6. Schneider, C. et al. Weather observations across the Southern Andes at $53^{\circ} \mathrm{S}$. Phys. Geogr. 24, 97-119 (2003).

7. Kilian, R., Hohner, M., Biester, H., Wallrabe-Adams, H. J. \& Stern, C. R. Holocene peat and lake sediment tephra record from the southernmost Chilean Andes (53-55 S). Rev. Geol. Chile 30, 23-37 (2003).

8. Wagner, S. et al. Transient simulations, empirical reconstructions and forcing mechanisms for the Mid-holocene hydrological climate in southern Patagonia. Clim. Dyn. 29, 333-355 (2007).

9. Endlicher, W. Patagonien-Klima- und agrarökologische Probleme an der Magellanstraße. Geogr. Rundschau 43, 143-151 (1991).

10. Jenny, B., Wilhelm, D. \& Valero-Garces, B. L. The Southern Westerlies in Central Chile: Holocene precipitation estimates based on a water balance model for Laguna Aculeo (335 50' S). Clim. Dyn. 20, 269-280 (2003).

11. Latorre, C. et al. in The Geology of Chile (eds Moreno, T. \& Gibbons, W.) 309-328 (The Geological Society, 2007). 
12. Trenberth, K. E. The role of eddies in maintaining the Westerlies in the Southern Hemisphere winter. J. Atmos. Sci. 44, 1498-1508 (1987).

13. Gill, A. E. Atmosphere-Ocean Dynamics (Academic, 1982).

14. Bianchi, C. \& Gersonde, R. Climate evolution at the last deglaciation: The role of the Southern Ocean. Earth Planet. Sci. Lett. 228, 407-424 (2004).

15. Kaiser, J., Schefuss, E., Lamy, F., Mohtadi, M. \& Hebbeln, D. Glacial to Holocene changes in sea surface temperature and coastal vegetation in north central Chile: High versus low latitude forcing. Quat. Sci. Rev. 27, 2064-2075 (2008).

16. Koutavas, A. \& Sachs, J. P. Northern timing of deglaciation in the eastern equatorial Pacific from alkenone paleothermometry. Paleoceanography 23, PA4205 (2008).

17. Liu, Z., Brady, E. \& Lynch-Stieglitz, J. Global ocean response to orbital forcing in the Holocene. Paleoceanography 18, 1041 (2003).

18. Masson, V. et al. Holocene climate variability in Antarctica based on 11 ice-core isotopic records. Quat. Res. 54, 348-358 (2000).

19. McManus, J., Francois, R., Gherardi, J-M., Kelgwin, L. D. \& Brown-Leger, S. Collapse and rapid resumption of Atlantic meridional circulation linked to deglacial climate changes. Nature 428, 834-837 (2004).

20. Cane, M. A. The evolution of El Nino, past and future. Earth Planet. Sci. Lett. 230, 227-240 (2005).

21. Schneider, C. \& Gies, D. Effects of El Nino-southern oscillation on southernmost South America precipitation at $53^{\circ} \mathrm{S}$ revealed from NCEP-NCAR reanalyses and weather station data. Int. J. Clim. 24, 1057-1076 (2004).

22. Anderson, R. F. et al. Wind-driven upwelling in the Southern Ocean and the deglacial rise in atmospheric $\mathrm{CO}_{2}$. Science 323, 1443-1448 (2009).

23. Tschumi, T., Joos, F. \& Parekh, P. How important are Southern Hemisphere wind changes for low glacial carbon dioxide? A model study. Paleoceanography 23, PA4208 (2008).

24. Monnin, E. et al. Evidence for substantial accumulation rate variability in Antarctica during the Holocene, through synchronization of $\mathrm{CO}_{2}$ in the Taylor Dome, Dome C and DML ice cores. Earth Planet. Sci. Lett. 224, 45-54 (2004).
25. Brovkin, V., Kim, J. H., Hofmann, M. \& Schneider, R. A lowering effect of reconstructed Holocene changes in sea surface temperatures on the atmospheric $\mathrm{CO}_{2}$ concentration. Glob. Biogeochem. Cycles 22, GB1016 (2008).

26. Vera, C., Silvestri, G., Liebmann, B. \& Gonzalez, P. Climate change scenarios for seasonal precipitation in South America from IPCC-AR4 models. Geophys. Res. Lett. 33, L13707 (2006).

27. Kalnay, E. et al. The NCEP/NCAR 40-year reanalysis project. Bull. Am. Meteorol. Soc. 77, 437-471 (1996).

28. New, M., Lister, D., Hulme, M. \& Makin, I. A high-resolution data set of surface climate over global land areas. Clim. Res. 21, 1-25 (2002).

29. Berger, A. \& Loutre, M. F. Insolation values for the climate of the last 10 million years. Quat. Sci. Rev. 10, 297-317 (1991).

\section{Acknowledgements}

We thank R. Gersonde and R. Tiedemann for comments and suggestions. M. Arevalo and O. B. Urrea are acknowledged for technical and logistic support during various campaigns with RV Gran Campo II and laboratory work in Trier, respectively. Financial support was made available through the GFZ-Potsdam, the Gary Comer Science and Education Foundation (CSEF) as well as through DFG grants AR 367/6-1, Ki-456/10, and La 1273/7-1.

\section{Author contributions}

All authors interpreted the results and contributed to the final manuscript. F.L. and R.K. wrote the final version of the manuscript. J-P.F. performed the pollen analyses. H.W.A. and T.S. carried out most of the remaining analytical work. M.P. contributed climatological background data and analyses.

\section{Additional information}

The authors declare no competing financial interests. Supplementary information accompanies this paper on www.nature.com/naturegeoscience. Reprints and permissions information is available online at http://npg.nature.com/reprintsandpermissions. Correspondence and requests for materials should be addressed to F.L. 